\title{
Comparative Analysis of Rainfed and Dry Season Rice Farming in Value Chain Development Programme in Ayamelum Local Government Area- Anambra State
}

\author{
Obianefo C.A. ${ }^{1}$, Aguaguiyi N.F. ${ }^{2}$, Umebali E.E. ${ }^{3}$, Ezeano C.I. ${ }^{4}$ \\ ${ }^{1}$ Department of Agricultural Economics and Extension, Nnamdi Azikiwe University, PMB 5051 Awka, Nigeria \\ ${ }^{2}$ Department of Agribusiness and Management, Michael Okpara University, Umudike \\ ${ }^{3,4}$ Department of Agricultural Economics and Extension, Nnamdi Azikiwe University, PMB 5051 Awka, Nigeria
}

\begin{abstract}
Nigeria agricultural sector rely heavily on rainfed farming system, this has seen a wide gap in the annual rice demandsupply trend in the country. Thus, the importance of the study on comparative analysis of rainfed and dry season rice farming in value chain development programme in Ayamelum Local Government Area, which focused primarily on socioeconomic characteristics, profitability, and challenges faced by rice farmers in the area cannot be overemphasized. The study used a multi-stage sampling technique to elicit information from 70 rainfed and 30 dry season rice farmers. Combination of statistical tools of the descriptive, budgetary model and inferential statistics of unequal variance t-test was utilized. The finding had a mean age was 47 years and 46 years for rainfed and dry season respectively. This suggests that dry season rice farmers are younger in the area. Also, the mean farming experience was found to be 11 years and 15 years, this equally suggest that dry season rice farmers are better experienced in the area. The mean farm size of 1.98ha for rainfed against 1.14ha for dry season rice farming suggests that more lands are available for rainfed rice farming. Furthermore, the difference in profit was $\$ 72,794.81$ significant at $t$-value of $22.83 * *$. Some of the challenges recorded by rain-fed rice farmers include; cattle menace, high cost of labour, and competition. The challenges recorded by dry season rice farmers include; high cost of pumping machine, more incidence of birds attack, and high cost of inputs. Evidently, dry season rice farming is more profitable.
\end{abstract}

Keywords: Rainfed, Net returns, Benefit-cost ratio, Operational expenses

\section{Introduction}

According to the International Rice Research Institute (IRRI) (2013), rice is a staple food for more than 3.5 billion people in the world. Rice is an important cash crop in Nigeria that has been found to thrive under four main ecologies (rainfed upland, shallow swamp \& inland valley swamp, irrigated lowland, and mangrove or tidal swamp ecology) suitable for different rice varieties (Imolehin and Wada, 2005:12).

United State Department of Agriculture (USDA) (2014), asserts that rice is one of the fastest growing commodities in Nigeria's food basket with likelihood of continued growth, increased demand for rice in Nigeria is attributed to rapid population growth, urbanization and people's preference for rice as convenience food (Akande, 2003; USDA, 2014).

Foyeku and Rice Millers, Importers and Distributors Association of Nigeria (RIMIDAN) (2019), opined than annual rice demand in Nigeria is 7 million tonnes of milled rice but paddy production as at December ending 2017 was 5 million tonnes. These 5 million tonnes represents about $56 \%$ milled rice, this suggests that rice farmers in Nigeria only contributed 2.5 million tonnes to the quantity demanded. Thus, a huge gap (4.5 million metric tonnes) exist in the demand-supply chain in Nigeria and the deficit is bridged by importation. Despite the suitable ecology and edaphic rice environment for rice production, Nigeria is battling to attain self-sufficiency in rice production and supply (Imolihen and Wada, 2005).

Rice production in Nigeria is mainly in the hand of smallscale rice growers cultivating about 0.5 to 3 hectares, these small-scale farmers supply about $80 \%$ of rice produced in Nigeria (IRRI, 2013). Though, attempt to increase rice production in Nigeria, the federal government loaned out \#43 billion through Anchor Borrowers Programme of the federal ministry of agriculture to 293,000 rice farmers which in turn produced rice that was sold at $\$ 193$ billion (Ogbeh, 2018). This noble gesture of the federal government increased paddy output from 5 million tonnes in 2015 to 17 million tonnes in 2018. According to the Federal Ministry of Agriculture and Rural Development (FMARD, 2018), Nigeria will soon export her excess parboiled rice to Liberia, Ghana and Sierra Leone. This means that international market waits for rice farmers in Nigeria.

On the other hand, Anambra state alone demands 320,000mt of rice per annum (Anambra state Agricultural Development Programme (ADP, 2018). Thus, to meet this huge demand, Anambra state value chain development programme (ANSVCDP) encouraged rice farmers participating in the programme with the provision of tube-well, water pumping machine and dry season farm inputs at $50 \%$ subsidy. This will enable them to farm all year round. 


\section{International Journal of Science and Research (IJSR) \\ ISSN: 2319-7064}

ResearchGate Impact Factor (2018): 0.28 | SJIF (2018): 7.426

The need to expose the gain of dry season rice farming as against the rainfed cannot be overemphasized as several research authors have revealed in their study that irrigated rice farming is more profitable since only fewer farmers have the capacity to cultivate at this time. Babatunde et al (2016), assert that rice output under irrigation system has a wide gap with that of rainfed and the veritable profit from the enterprise can serve as a poverty alleviation programme to rural youths. Since Sani and Giroh (2014), suggests that younger farmers with a mean age of 46 years cultivating 1.96ha reported land, labour and agro-chemical as an important production factor under irrigation system, efforts should be directed at making such inputs factors available to the farmers.

\section{Objective}

The main aim of this study is to compare the net gain of rainfed and dry seasons rice farming in value chain development programme in Ayamelum local government area, Anambra state. specifically; the study tends to:

1) Identify the socioeconomic characteristics of rice farmers involved with rain-fed and dry season rice farming in the study area,

2) Estimate the profitability of rainfed and dry season rice farming in the study area,

3) Compare the difference in the profit of rainfed and dry season rice farming in the area, and

4) Observe the challenges facing rain-fed and dry season rice paddy farmers in the study area.

\section{Hypotheses}

There is no significant difference in the profit of rainfed and dry season rice farmers in the study area.

\section{Research Methodology}

\section{The Study Area}

The study was carried out in Ayamelum local government area, Anambra state. Anaku is the headquarter of the local government area. The 7 communities that make up Ayamelum local government area includes; Omor, Umueje, Omasi, Igbakwu, Umumbo, Anaku, and Ifite-Ogwari with a population of 158,152 (NPC, 2006). 2558 (1450 male and 1108 female) rice farmers are participating in the IFAD assisted Value Chain Development Programme in the area (Anambra state value chain database, 2019). Ayamelum is situated between Latitudes $6^{\circ} 54^{\prime} .95 " \mathrm{~N}$ and Longitude $6^{\circ} 99^{\prime} .38^{\prime \prime}$ E respectively, with an estimated land area of $598 \mathrm{~km}^{2}$ and density of $355.4 / \mathrm{km}^{2}$.

\section{Sampling Procedure and Method of Data Collection}

List of participating rice farmers was made available by the Anambra state value chain development programme office and 100 farmers were drawn from the sample frame as the study representative. Multi-stage sampling technique was used to collect data from the 100 rice farmers separated by 70 rain-fed and 30 dry seasons rice farmers. Stage one: 2 villages were randomly selected from each of the 7 communities in the study area to make it 14 villages. Stage two: 5 rice farmers were randomly selected from the 14 villages to make it a total of 70 rain-fed rice farmers. Also, 3 communities (Omor, Umumbo, and Anaku) were purposely selected in the fourth stage because of the presence of irrigation water source like Anaku-ude spring that cut across the 3 selected communities. Furthermore, 2 villages were randomly selected to make it a total of 6 villages. Finally, 5 dry season rice farmers were randomly sampled to make it a total of 30 dry season rice farmers for the study.

\section{Method of Data Analysis}

A combination of analytical tools which includes; descriptive statistics, budgetary model and inferential statistics of unequal variance t-test were used. Objective 1, 3 and 4 were achieved with descriptive statistics. Objective 2 was achieved with a budgetary model. The model is presented below as:

A) Descriptive statistics for objective 1, 3 and 4 stated as;

$$
\overline{\mathrm{X}}=\sum \frac{\mathrm{FX}}{\mathrm{n}} \ldots \ldots q n \cdot 1
$$

Where; $\overline{\mathrm{X}}=$ mean, $\mathrm{X}=$ variable outcome, $\mathrm{n}=$ sample size, and $\mathrm{F}=$ frequency.

B) Budgetary model for objective 3 was stated as;

$$
\mathrm{NG}=\mathrm{TR}-\mathrm{TC} \ldots \text { Eqn. } 2.1
$$

$$
\mathrm{TC}=\mathrm{TFC}+\mathrm{TVC} \ldots . . \text { Eqn } .2 .2
$$

Where: $\mathrm{NG}=$ Net gain, $\mathrm{TR}=$ Total revenue, $\mathrm{TC}=$ Total cost, $\mathrm{TFC}=$ Total fixed cost, and $\mathrm{TVC}=$ Total variable cost .

C) Unequal variance t-test for hypothesis one was stated as;

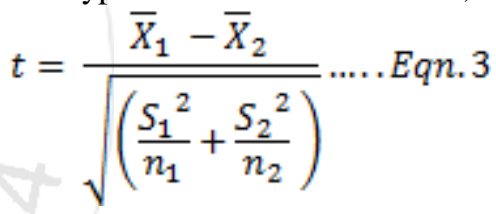

Where:

$\overline{\mathrm{X}}_{1}=$ Mean net gain for dry season rice paddy production

$\overline{\mathrm{X}_{2}}=$ Mean net gain for rain-fed rice paddy production

$\mathrm{S}_{1}^{2}=$ Variance of dry season net gain

$\mathrm{S}_{2}{ }^{2}=$ Variance of rain-fed net gain

$\mathrm{n}_{1}$ and $\mathrm{n}_{2}=30$ and 70 sample size for dry season and rain-fed respectively

\section{Results and Discussions}

\section{Socioeconomic characteristics of rice paddy farmers in the study area}

The finding on socioeconomic characteristics in table 1 shows that the majority $(58.57 \%$ and $66.67 \%)$ of the rice farmers in the rainfed and dry season were male respectively. the mean age for rainfed and dry season rice farmers was equally found to be 47 and 46 years respectively. This suggests that rice farmers in the programme are active and energetic. Most at times, experience comes with age, thus, the finding revealed a mean farming experience of 11 years for rainfed and 15 years for dry seasons rice farming.

The difference in farming experience could be as a result of technicalities involved in irrigated rice farming. This was further proven by their level of education. The majority $(38.57 \%)$ of the rainfed farmers attended secondary school and the same with a majority $(43.33 \%)$ of the dry season

\section{Volume 8 Issue 7, July 2019 www.ijsr.net}




\section{International Journal of Science and Research (IJSR) \\ ISSN: 2319-7064 \\ ResearchGate Impact Factor (2018): 0.28 | SJIF (2018): 7.426}

farmers but the difference in percentage is an indication that dry season rice farmers are more educated.

Furthermore, information on farm size shows that the mean farm size was 1.98 hectares for rainfed and 1.14 hectare for the dry season. This suggests that more land is available for rainfed rice farming than the dry season rice farming. Thus, to avert the paucity of land supply for irrigated rice farming, efforts should be directed into making more irrigable land available to the farmers.

Even the mean extension contacts of 2 time per cycle for rainfed and 3 times per cycle for dry seasons rice farming point to it that efforts are being directed to encourage offseason rice farming as a way out to surmount the demandsupply deficit highlighted in the study.
Table 1: Socioeconomic characteristics of rice paddy farmers in the area

\begin{tabular}{|c|c|c|c|c|c|c|c|}
\hline \multirow{2}{*}{$\mathrm{Sn}$} & \multirow[b]{2}{*}{ Variable } & \multicolumn{2}{|c|}{ Frequency } & \multicolumn{2}{|c|}{$\begin{array}{c}\text { Percentage } \\
\%\end{array}$} & \multicolumn{2}{|c|}{ Mean } \\
\hline & & $\begin{array}{c}\text { Main } \\
\text { seasons } \\
(\mathrm{n}=70) \\
\end{array}$ & $\begin{array}{c}\text { Dry } \\
\text { season } \\
(\mathrm{n}=30)\end{array}$ & Main & Dry & Main & Dry \\
\hline \multirow[t]{5}{*}{1} & Age: & & & & & & \\
\hline & $\leq 30$ & 4 & 1 & 5.71 & 3.33 & & \\
\hline & $31-40$ & 14 & 10 & 20.00 & 33.33 & & \\
\hline & $41-50$ & 9 & 12 & 12.86 & 40.00 & 47.47 & 46.23 \\
\hline & $51 \&$ above & 43 & 7 & 61.43 & 23.33 & & \\
\hline \multirow[t]{4}{*}{2} & Level of education & & & & & & \\
\hline & Primary & 20 & 5 & 28.57 & 16.67 & & \\
\hline & Secondary & 27 & 13 & 38.57 & 43.33 & & \\
\hline & Tertiary & 23 & 12 & 32.86 & 40.00 & & \\
\hline \multirow[t]{5}{*}{3} & Farming Experience & & & & & & \\
\hline & $\leq 5$ & 3 & - & 4.29 & - & & \\
\hline & $6-15$ & 55 & 21 & 78.57 & 70.00 & 11.26 & 14.73 \\
\hline & $16-25$ & 12 & 7 & 17.14 & 23.33 & & \\
\hline & $26 \&$ above & - & 2 & - & 6.67 & & \\
\hline \multirow[t]{5}{*}{4} & Extension contact & & & & & & \\
\hline & $\leq 1$ & 11 & 8 & 15.71 & 26.67 & & \\
\hline & $2-3$ & 51 & 12 & 72.86 & 40.00 & 2.14 & 2.60 \\
\hline & $4-5$ & 8 & 10 & 11.43 & 33.33 & & \\
\hline & $6 \&$ above & - & - & - & - & & \\
\hline \multirow[t]{4}{*}{5} & Farm size (ha) & & & & & & \\
\hline & $\leq 1.9$ & 35 & 25 & 50.00 & 83.33 & & \\
\hline & $2-3$ & 25 & 4 & 35.71 & 13.33 & 1.98 & 1.14 \\
\hline & $4 \&$ above & 10 & 1 & 14.29 & 3.33 & & \\
\hline
\end{tabular}

Source: Field Survey Data, May 2019.

Table 2: Estimation of the profitability of rainfed and dry season rice farming

\begin{tabular}{|c|c|c|c|c|c|c|c|c|}
\hline \multirow[t]{2}{*}{ Items } & \multicolumn{4}{|c|}{ Rainfed } & \multicolumn{4}{|c|}{ Dry Season } \\
\hline & Quantity & Unit price $(\mathbb{N})$ & Amount $(\#)$ & Value (\#) & Quantity & Unit price $(\mathbb{N})$ & Amount $(\cong)$ & Value ( \\
\hline $\begin{array}{c}\text { Revenue: } \\
\text { Sales of paddy }(\mathrm{kg})\end{array}$ & $9,155.71$ & 110 & $1,007,128.57$ & 5 & $5,830.00$ & 130 & $757,900.00$ & \\
\hline Yield/ha & 4.624 tons & & & A & 5.114 tons & $a$ & & \\
\hline Variable cost: & & 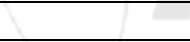 & & +2 & - & +2 & & \\
\hline N.P.K Fertilizer (kg) & 438.17 & 130 & 56962.10 & & 219.63 & 140 & 30748.2 & \\
\hline Urea $(\mathrm{kg})$ & 200.50 & 140 & 28070.00 & & 108.93 & 140 & 15250.2 & \\
\hline Seed $(\mathrm{kg})$ & 104.00 & 250 & 26000.00 & & 53.20 & 300 & 15960 & \\
\hline Herbicide (liters) & 7.92 & 1500 & 11880.00 & 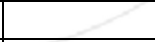 & 2.28 & 3000 & 6840 & \\
\hline Insecticide (liters) & 3.96 & 1500 & 5940.00 & 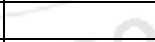 & 4.56 & 1500 & 6840 & \\
\hline Fungicide (liters) & 3.96 & 1400 & 5544.00 & 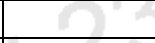 & 2.28 & 3000 & 6840 & \\
\hline Mechanical labour (ha) & 1.98 & 30000 & 59400.00 & $8=$ & 1.14 & 30000 & 34200 & \\
\hline Hired labour (man-day) & 235 & 1200 & 282000.00 & $=$ & 131.87 & 1500 & 197805 & \\
\hline TVC & & & & 475796.10 & & & & 314483.40 \\
\hline Fixed Cost & & & & & & & & \\
\hline Land rent per cycle (ha) & 1.98 & 16000 & $31,680.00$ & & 1.14 & 18000 & 20520 & \\
\hline Dep. on Knapsack sprayer & 3 & $15000 / 5 \mathrm{yrs}$ & 900.00 & & 4 & $15000 / 5 \mathrm{yrs}$ & 12000 & \\
\hline Dep. on pumping machine & 2 & $70000 / 5 y r s$ & $28,000.00$ & & 3 & $70000 / 5 \mathrm{yrs}$ & 56000 & \\
\hline Dep. on Sack bag & 300 & 50/6mth. & $5,000.00$ & & 450 & 50/6mth. & 3750 & \\
\hline TFC & & & & $65,580.00$ & & & & $92,270.00$ \\
\hline TC (TVC+TFC) & & & $541,376.10$ & & & & $406,753.40$ & \\
\hline Gross margin (TR-TVC) & & & & $531,332.47$ & & & & $443,416.60$ \\
\hline Net gain (TR-TC) & & & & $465,752.47$ & & & & $351,146.60$ \\
\hline Benefit-Cost Ratio & & & & 0.98 & & & & 1.41 \\
\hline Return on Investment & & & & 0.86 & & & & 0.86 \\
\hline
\end{tabular}

Source: Field Survey Data, May 2019.

The profitability of rainfed and dry season rice farming calculated in table 2 had a mean paddy output of 4.624 tons/ha for rainfed and 5.114 tons/ha for the dry season. This suggests that dry seasons rice farming yields more grains since all the variables of production are subjected to the farmer's control at dry season. The farm is equally exposed to more sun-light for photosynthesis. The total cost incurred for rainfed farming under 1.98 ha. was $\$ 541,376.10$ ( $\$ 288,573.79 / \mathrm{ha}$ ) and $\$ 406,753.40$ ( $\$ 388,961.93 / \mathrm{ha}$ ) was incurred for the dry season under the 1.14 ha. The enterprise

\section{Volume 8 Issue 7, July 2019 www.ijsr.net}




\section{International Journal of Science and Research (IJSR) \\ ISSN: 2319-7064}

ResearchGate Impact Factor (2018): 0.28 | SJIF (2018): 7.426

received revenue of $\$ 1,007,128.57$ and $\$ 757,900.00$ for rainfed and dry season respectively. The benefit-cost ratio of 0.98 for rainfed and 1.41 for the dry season is an indication that rice farming under rainfed can cover for its operational expenses by $98 \%$ and $141 \%$ for the dry season in a short run.

The production had a net-returns of $\$ 465,752.47$ (\$235,228.52/ha) for rainfed and \$351,146.60 ( $\$ 308,023.33 / \mathrm{ha}$ ) for dry season respectively. Finally, both seasons had a return on investment of 0.86 signifying that $\$ 1$ capital investment in rice farming will return a profit of \#0.86 to the business.

The difference in net gain among rain-fed and dry season rice paddy farming

The researcher used the difference in mean to ascertain the net gain of rice production at both seasons, finding revealed that the farmers make an extra $\$ 72,794.81$ for engaging in dry season rice paddy production. Apart from ensuring continued availability/supply of rice to the food basket in the Nigeria economy, it also proved to be more profitable.
Table 3: Mean difference in the profitability of rice farming

\begin{tabular}{|c|c|c|}
\hline Production season & Mean farm size (ha) & Net gain ( $)$ \\
\hline Main seasons & 1.98 & 465752.47 \\
\cline { 2 - 3 } & 1 & 235228.52 \\
\hline Dry season & 1.14 & $351,146.60$ \\
\cline { 2 - 3 } & 1 & $308,023.33$ \\
\hline The difference in a net gain & & $\mathbf{7 2 , 7 9 4 . 8 1}$ \\
\hline
\end{tabular}

Source: Field Survey Data, May 2019.

\section{Challenges faced by both rain-fed and dry season rice paddy farmers}

The challenges faced by rice paddy farmers at any of the production seasons was captured in table 7 above. Information on main season rice paddy farming shows that the major problems encountered in main season rice farming as shown by the following percentages: $95.71 \%, 71.43 \%$, $61.43 \%, 48.57 \%$, and $42.86 \%$ were cattle menace, competition, scarcity of labour, high cost of labour, and high incidence of pest and diseases respectively. Also, major challenges faced by dry season rice paddy farming had the following percentages; $96.67 \%, 90.00 \%, 76.67 \%, 70.00 \%$, and $66.67 \%$ were the high cost of inputs, increase in bird attack, cattle menace, expensive water pumping machine, and poorly developed irrigation facility respectively.

Table 4: Challenges of rice paddy production at both main and dry seasons

\begin{tabular}{|c|c|c|c|c|c|c|c|}
\hline \multirow{2}{*}{ Sn } & \multirow{2}{*}{ Challenges } & \multicolumn{2}{|c|}{ Frequency } & \multicolumn{2}{c|}{ Percentage (\%) } & \multicolumn{2}{c|}{ Ranking } \\
\cline { 2 - 8 } & & Main season & Dry season & Main season & Dry season & Main season & Dry season \\
\hline 1 & Scarcity of labour & 43 & 5 & 61.43 & 16.67 & 3 & 10 \\
\hline 2 & High cost of input & 10 & 29 & 14.29 & 96.67 & 10 & 1 \\
\hline 3 & Flood & 14 & - & 20.00 & - & 8 & 12 \\
\hline 4 & Drought & - & 2 & - & 6.67 & 13 & 11 \\
\hline 5 & High incidence of pest and diseases & 30 & 12 & 42.86 & 40.00 & 5 & 7 \\
\hline 6 & Increased bird attack & 13 & 27 & 18.57 & 90.00 & 9 & 2 \\
\hline 7 & Control of water is expensive & 20 & 9 & 28.57 & 30.00 & 6 & 9 \\
\hline 8 & Lack of market for the produce & 8 & - & 11.43 & - & 11 & 12 \\
\hline 9 & Competition & 50 & 12 & 71.43 & 40.00 & 2 & 7 \\
\hline 10 & High cost of labour & 34 & 20 & 48.57 & 66.67 & 4 & 5 \\
\hline 11 & Cattle menace & 67 & 23 & 95.71 & 76.67 & 1 & 3 \\
\hline 12 & Expensive water pumping equipment & 17 & 21 & 24.29 & 70.00 & 7 & 4 \\
\hline 13 & Poorly developed irrigation facility & 4 & 20 & 5.71 & 66.67 & 12 & 5 \\
\hline
\end{tabular}

Source: Field Survey Data, May 2019. *multiple responses were allowed.

Table 5: Significant difference in the profitability of rice farming for both season

\begin{tabular}{|l|l|l|l|l|l|l|}
\hline \multicolumn{1}{|c|}{ Variable } & Obs. & \multicolumn{1}{c|}{ Mean } & \multicolumn{1}{c|}{ Std. Err. } & Std. Dev. & \multicolumn{2}{c|}{$[95 \%$ Conf. Interval] } \\
\hline Dry season & 30 & $308,023.33$ & 3334.638 & 18264.57 & 304503.2 & 318143.4 \\
\hline Main season & 70 & $235,228.52$ & 28.56451 & 238.9878 & 235143 & 235256.9 \\
\hline Combined & 100 & $271,625.93$ & $1,681.60$ & $9,251.78$ & $269,823.10$ & $276,700.15$ \\
\hline Diff & & $72,794.81$ & 3334.761 & & 69303.06 & 82943.68 \\
\hline$t=\mathbf{2 2 . 8 2 7 2}$ & \multicolumn{7}{|c|}{ Satterthwaite's degrees of freedom } & 29.0043 & \\
\hline
\end{tabular}

Source: Field Survey Data, May 2019.

Two samples unpaired and unequal variance t-test was used to observe if a significant difference exists in the net gain of the rainfed and dry season rice farming in Ayamelum LGA. The samples had 70 main season rice paddy farmers and 30 dry season rice paddy farmers in the study, finding shows a net gain difference of $\$ 72,794.81$ and a t-value of $22.8272 * *$ significant at 0.000 probability level. Thus, the null hypothesis one is rejected hence the difference in net gain is significant in the study area.

\section{References}

[1] Agricultural Transformation Agenda (ATA) (2010). Rice Transformation Project Proposal Report submitted to the Federal Ministry of Agriculture and Rural Development, Abuja Nigeria.

[2] Akande, T. (2003). The Rice Sector in Nigeria. United Nation Crop Project (UNCP) Country.

[3] Babatunde R.O., Salami M.F., Mohammed B.A. (2016). Determinants of Yield Gap in Rainfed and Irrigated Rice Production: Evidence from Household Survey in Kwara State. Department of Agricultural Economics 


\section{International Journal of Science and Research (IJSR) \\ ISSN: 2319-7064}

ResearchGate Impact Factor (2018): 0.28 | SJIF (2018): 7.426

and Farm Management. University of Ilorin. Invited paper presented at the 5th International Conference of the African Association of Agricultural Economists, September 23-26, 2016, Addis Ababa, Ethiopia.

[4] Foyeku S. and Rice Millers, Importers and Distributors Association of Nigeria (2017). Nigeria cannot attain self-sufficiency in rice production by 2018 . Retrieved online, January 12, 2018 from www.shipandport.com.

[5] Imolehin, E. D. and Wada, A. C. (2005). Meeting the rice production and consumption demands of Nigeria with improved technologies. National Cereals Research Institute Badeggi Niger State, Nigeria. Pp12.

[6] International Rice Research Institute (IRRI, 2013). World rice statistics. Retrieved from http://ricestat.irri.org:8080/wrs.

[7] NPC., 2006. National Population Census results. Federal Government of Nigeria Official gazette 24, (94): 6-7.

[8] Ogbeh A. (2018). Nigeria's Local rice output hits 17 million tonnes. Federal ministry of agriculture and rural development. Retrieved online January 12, 2019 from www.shipandport.com.ng.

[9] Tashikalma A. K., Sani R. M. and Giroh D. Y. (2014). Comparative Profitability Analysis of Selected Rainfed and Irrigated Food Crops in Adamawa State, Nigeria. global journal of pure and applied sciences vol. 20, 2014: 77-87. www.globaljournalseries.com.

[10] United State Department of Agriculture (2014): Agricultural Statistic. U.S. Government. Washington. Printing Office. DC Area (202) 512-1800.

Volume 8 Issue 7, July 2019 www.ijsr.net 